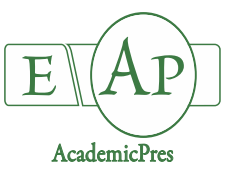

Molina-Corral FJ et al. (2021)

Notulae Botanicae Horti Agrobotanici Cluj-Napoca

Volume 49, Issue 1, Article number 12241

DOI: $10.15835 /$ nbha49112241

Research Article

\title{
Quality attributes during maturation of 'Golden Delicious' and 'Red Delicious' apples grown in two geographical regions with different environmental conditions
}

\author{
Francisco J. MOLINA-CORRAL ${ }^{1}$, Miguel ESPINO-DÍAZ ${ }^{1}$, \\ Juan L. JACOBO ${ }^{2}$, Scott D. MATTINSON ${ }^{3}$, John K. FELLMAN 3 , \\ David R. SEPÚLVEDA ${ }^{1}$, Gustavo A. GONZÁLEZ-AGUILAR ${ }^{4}$, \\ Nora A. SALAS-SALAZAR ${ }^{2}$, Guadalupe I. OLIVAS ${ }^{1 *}$ \\ ${ }^{I}$ Centro de Investigación en Alimentación y Desarrollo A.C., Av. Rio Conchos S/N, Cuauhtémoc, Chih., 31570, México; \\ aster3000@hotmail.com; javiermolina@ciad.mx; dsepulveda@ciad.mx; golivas@ciad.mx (*corresponding author) \\ ${ }^{2}$ Universidad Autónoma de Chihuahua, Facultad de Ciencias Agrotecnológicas, Calle Presa de la Amistad 2015 Cuauhtémoc, Chih., \\ 31510,México; jacobocuellarj@gmail.com;nora.salas09@yahoo.com.mx \\ ${ }^{3}$ Washington State University, Department of Horticulture and Landscape Architecture, Pullman, WA 99164-6414, USA; \\ dmattinson@wsu.edu; fellman@wsu.edu \\ ${ }^{4}$ Centro de Investigación en Alimentación y Desarrollo A.C., Carretera a la Victoria Km 0.6, Hermosillo, Son., México; \\ gustavo@ciad.mx
}

\begin{abstract}
Apples have distinctive quality attributes that may be defined by environmental conditions of the geographical regions where fruits are cultivated, such as temperature, solar radiation, photoperiod, and photothermic units. A three-year study was conducted to compare 'Golden Delicious' and 'Red Delicious' apples from two different regions, Washington, USA (WA) and Chihuahua, Mexico (CHIH). Apple samples were harvested weekly from early August to late October ( 120-180 days after full bloom - DAFB), and analysed for quality parameters. Geographic environmental data were obtained, and photoperiod, solar radiation, degree-days and photothermal units were calculated. Results show quality differences between $\mathrm{CHIH}$ and WA apples. WA shows a $\sim 5$-week delay in apple bloom, possibly due to the lower temperatures presented in WA. Apples from both regions required the same photoperiod, $\sim 2,222 \mathrm{~h}$, to attain the beginning of the ripening stage, which took more days (three weeks) for $\mathrm{CHIH}$ apples, most likely attributed to the higher elevation of CHIH orchards (2,062 vs. 763 masl). The main distinctive quality differences found between WA and $\mathrm{CHIH}$ apples were firmness and aroma volatile compounds. $\mathrm{CHIH}$ apples presented substantially higher amounts of aroma compounds. WA apples showed greater firmness, probably due to lower photothermal units. Using all firmness data (both varieties, both growing zones) a remarkable correlation was found between firmness and photothermal units $(\mathrm{R}=0.89)$, which may suggest firmness could be improved by the manipulation of degree days and photoperiod, that is, temperature and light.
\end{abstract}

Keywords: aroma volatiles; elevation; firmness; Malus domestica; photoperiod; photothermal units; solar radiation

Received: 26 Jan 2021. Received in revised form: 16 Mar 2021. Accepted: 17 Mar 2021. Published online: 24 Mar 2021.

From Volume 49, Issue 1, 2021, Notulae Botanicae Horti Agrobotanici Cluj-Napoca journal will use article numbers in place of the traditional method of continuous pagination through the volume. The journal will continue to appear quarterly, as before, with four annual numbers. 


\section{Introduction}

Apples are important fruits worldwide, and Washington (WA) and Chihuahua (CHIH) are the top apple-producing states in the US and Mexico. 'Golden Delicious' (GD) and 'Red Delicious' (RD) apples are among the most cultivated varieties in both areas and are highly valued for their quality (USDA, 2020; SIAP, 2020).

Apple quality characteristics may be affected by factors such as environmental conditions (Dal Cin et al., 2007; Timilsina and Tripathi, 2019), which may also modify the blooming time and maturation rate of the fruit (Dhanaraj et al., 1986; Guédon and Legave, 2008). Among the environmental characteristics that can vary between WA and CHIH include temperature, solar radiation, and photoperiod, which are defined in part by the altitude and latitude of the zones (Drogoudi and Pantelidis, 2011; Jin et al., 2017; Alessandrini et al., 2019; Timilsina and Tripathi, 2019).

The onset of flowering is hastened by temperature in pears, apples, and leguminous species such as chickpea, which is explained by the fulfilment of the heat requirements (Keatinge et al., 1998; Guédon and Legave, 2008; Kanchan and Bhatia, 2014). The time span in the apple developmental cycle required to reach a given ripening stage seems to be longer in high altitude zones, probably due to a delay in ethylene biosynthesis (Dhanaraj et al., 1986; Danesin et al., 2004; Dal Cin et al., 2007). The ripening rate may be affected by the photoperiod; according to Keatinge et al. (1998), temperate leguminous species matured earlier in zones with more extended photoperiod.

Elevation may affect fruit quality. According to Faniadis et al. (2010), cherries of the highest elevations have better quality compared to those cultivated in the lowest elevations (Danesin et al., 2004; Dal Cin et al., 2007). According to Timilsina and Tripathi (2019), lower acidity is observed on mandarins (Citrus reticulata Blanco) as the elevation increased. Also, some studies report that elevation has a marked influence on the aroma production of grapes (Jiang et al., 2013; Xu et al., 2015; Alessandrini et al., 2019).

Day length and light intensity may also have an impact on fruit quality. According to Choudhury et al. (2008), sucrose synthesis in bananas (Musa acuminata, AAA group) increases with increasing light exposure. Other works show that solar radiation favours red coloration and a more developed yellow colour in apples suggesting there is an induction of the synthesis of anthocyanins at greater light intensity (Jakopic et al., 2007; Drogoudi and Pantelidis, 2011; Baiamonte et al., 2016; Ordoñez et al., 2016).

Another interesting environmental parameter that may be related to apple quality is the photothermal unit (PTU), which is the product of the degree day (GDD favourable thermal unit for the occurrence or continuation of a biological process) times the sunshine hours. To the best of our knowledge, the effect of PTU on fruit quality has not been reported.

Therefore, to better understand how environmental factors affect apple quality, the present study characterized the environmental conditions of two different apple-producing zones, Washington (WA) and Chihuahua (CHIH), and evaluated the quality development of 'Golden Delicious' and 'Red Delicious' apples during the maturation of the fruits. Differences in flowering, internal ethylene concentration IEC, colour, firmness, and aroma volatiles of apples in the two zones were evaluated in relationship with temperature, photoperiod, solar radiation altitude, elevation and photothermal units, to elucidate whether these quality attributes may be related to environmental conditions.

\section{Materials and Methods}

\section{Plant material}

A three consecutive year study was simultaneously conducted on 'Golden Delicious' and 'Red Delicious' apples grown in Cuauhtémoc, Chihuahua (Mexico) and Pullman, Washington (USA). Characteristics of both regions (latitude, longitude, and elevation) are shown in Table 1 . The study was carried out on commercial 
orchards with general orchard management procedures. Apple trees on MM106 rootstocks 25 years old in Washington (WA) and 30 years old in Chihuahua $(\mathrm{CHIH})$ were used for this experiment. A total of 20 trees per each variety were used. A total of 60 apples ( 3 apples per tree) were harvested, from the external western side of the tree canopy to avoid fruit quality variations due to fruit position on canopy. Fruit sampling was conducted on a weekly basis from August to October, corresponding to 130 to 176 days after full bloom (DAFB). Samples from immature to mature stages of development were collected, and evaluated for maturity parameters, IEC, acidity, total soluble solids, colour, firmness and volatile compounds.

Table 1. Apple orchards geographic data in Washington, USA (WA) and Chihuahua, Mexico (CHIH)

\begin{tabular}{|c|c|c|}
\hline & WA & CHIH \\
\hline Latitude & $46^{\circ} 43^{\prime} 53.28^{\prime \prime} \mathrm{N}$ & $28^{\circ} 24^{\prime} 19.21^{\prime \prime} \mathrm{N}$ \\
\hline Longitude & $117^{\circ} 10^{\prime} 13.21^{\prime} \mathrm{W}$ & $106^{\circ} 50^{\prime} 03.11^{\prime} \mathrm{W}$ \\
\hline Elevation & $763 \mathrm{~m}$ & $2062 \mathrm{~m}$ \\
\hline
\end{tabular}

WA: Pullman, WA, USA; CHIH: Cuauhtémoc, Chih., México

\section{Geographic environmental data, degree-days and photothermal units}

Weather data was collected from two weather stations: UNIFRUT weather station at Cuauhtémoc, Chihuahua, Mexico, and Paradise creek weather station at Pullman, Washington. Maximum, minimum, and average temperature were recorded. Meteorological indices, photoperiod, solar radiation, degree days and photothermal units, were calculated from flowering until apples reached $\sim 1 \mu \mathrm{L} \mathrm{L}^{-1}$ IEC (Tables 2 and 3).

The total amount of heat required for an organism to develop from one developmental stage to another in its life cycle is calculated in units called growing degree-days (GDD), sometimes called heat units. GDD are the accumulated product of time and temperature between the developmental thresholds for each day. GDD were calculated according to the equation proposed by McMaster and Wilhelm (1997): GDD $=\left[T_{\max }+\right.$ $\left.\left.T_{\min }\right) / 2\right]-T_{b}$, where $T_{\max }$ and $T_{\min }$ are daily maximum air temperatures, respectively, and $T_{b}$ is base temperature, a threshold value below which no temperature contribution is effective. The $T_{b}$ used was $7{ }^{\circ} \mathrm{C}$, as proposed by Kronenberg (1983) for apple trees. Photothermal units (PTU) were calculated by using the equation given by Wilsie (1962) PTU= GDD * L; Where: GDD= Growing degree days; $\mathrm{L}=$ Maximum possible sunshine hours.

Table 2. Average temperatures in Washington, USA (WA) and Chihuahua, Mexico (CHIH), five weeks before bloom (an average of the three seasons)

\begin{tabular}{|c|c|c|c|c|}
\hline & $\operatorname{Max} \mathrm{T}\left({ }^{\circ} \mathrm{C}\right)$ & $\operatorname{Min} \mathrm{T}\left({ }^{\circ} \mathrm{C}\right)$ & Average $\mathrm{T}\left({ }^{\circ} \mathrm{C}\right)$ & Fluctuation $\left({ }^{\circ} \mathrm{C}\right)$ \\
\hline WA & 11.6 & 2.0 & 6.8 & 9.7 \\
\hline $\mathrm{CHIH}$ & 21.8 & 2.1 & 11.9 & 19.7 \\
\hline
\end{tabular}

Table 3. Days after full bloom required for attaining $\sim 1 \mu \mathrm{L} \mathrm{L}^{-1}$ IEC, cumulative photoperiod and solar radiation, from flowering to $\sim 1 \mu \mathrm{L} \mathrm{L}^{-1}$ IEC, for Golden Delicious and Red Delicious apples grown in Washington, USA (WA) and Chihuahua (CHIH)

\begin{tabular}{|c|c|c|c|c|c|}
\hline Cultivar & Zone & $\begin{array}{c}\text { DAFB }(\mathrm{IEC} \sim 1 \\
\left.\mu \mathrm{L} \mathrm{L} \mathrm{L}^{-1}\right)\end{array}$ & $\begin{array}{l}\text { Photoperiod }^{1} \\
\text { (light hours } \\
\text { summation) }\end{array}$ & $\begin{array}{l}\text { Solar radiation } \\
\qquad\left(\mathrm{Mj} / \mathrm{m}^{2}\right)^{3}\end{array}$ & $\begin{array}{l}\text { Photothermal } \\
\text { units }^{1}\end{array}$ \\
\hline \multirow{2}{*}{$\begin{array}{c}\text { 'Golden } \\
\text { Delicious' }\end{array}$} & $\mathrm{CHIH}$ & 169 & $2264(16.5) \mathrm{a}$ & 2050.0 & $24973(655.9) \mathrm{a}$ \\
\hline & WA & 151 & $2209(34.6) \mathrm{a}$ & 1819.6 & $18027(500.1) b$ \\
\hline 'Red & $\mathrm{CHIH}$ & 169 & $2279(7.6) \mathrm{a}$ & 2052.4 & $24963(658.2) \mathrm{a}$ \\
\hline Delicious' & WA & 144 & $2139(54.3) \mathrm{a}$ & 1535.7 & $17630(192.9) b$ \\
\hline
\end{tabular}

${ }^{1}$ Photoperiod and photothermal units were submitted to statistical analysis (standard error is presented in parenthesis).

Different upper-case letters among zone for each cultivar indicate statistically significant differences $(p \leq 0.05)$ 


\section{Internal ethylene concentration (IEC)}

Internal ethylene assays were performed by withdrawing a $0.2-0.5 \mathrm{~mL}$ gas sample from the core-space of a whole apple fruit through a $1 \mathrm{~mL} 23$-gauge hypodermic needle that had been pushed through the calyx end of the fruit into the core and sealed to the fruit with silicon grease. The needle was pushed into the calyx of the apples submerged in water and the needle was sealed with a rubber stopper. Gas samples were analysed using a gas chromatograph (Varian 3800; Walnut Creek, CA, USA) in CHIH and a HP-5890 (Agilent Technologies; Avondale, PA, USA) in WA equipped with a Hayesep Q Chrompack packed column (1.8 m, 3/8 ID, 20 mesh Silica) in (CHIH), and a $15 \mathrm{~m} \times 0.53 \mathrm{~mm}, 40 \mathrm{uM} \mathrm{HP}-\mathrm{PLOT}-\mathrm{Q}$ in (WA) and a flame ionization detector. The chromatographic conditions were as follows, initial oven temperature $60^{\circ} \mathrm{C}$, held for $2 \mathrm{~min}$, increased to 120 ${ }^{\circ} \mathrm{C}$ at $60^{\circ} \mathrm{C} / \mathrm{min}$, and held for $1.5 \mathrm{~min}$ in $(\mathrm{CHIH})$, and the oven temperature in (WA) was isothermal at 100 ${ }^{\circ} \mathrm{C}$. The carrier gas flow of helium was $30 \mathrm{~mL} / \mathrm{min}$ in $(\mathrm{CHIH})$, and the column carrier gas in (WA) was 8.0 $\mathrm{ml} / \mathrm{min}$. Ethylene values reported were the average of $10-15$ measurements.

\section{Colour and firmness measurements}

Ten fruits per treatment were used to evaluate skin colour and firmness. Two measurements per sample at two opposite locations on the equatorial area were assessed. Colour was measured with a Minolta CR-300 colorimeter (Konica Minolta; New Jersey, USA). Values were obtained using the Hunter Lab scale (L, a, b), and Hue angle was calculated. Apple firmness was determined with a Texture Analyser TA-XT2i (Stable Micro Systems; YL, England) in CHIH, and using a Topping penetrometer (Topping 1981) in WA. The tip used was an $11 \mathrm{~mm}$ diameter penetrometer tip. The maximum force needed to penetrate the peeled flesh, over a distance of $10 \mathrm{~mm}$ at a speed of $10 \mathrm{~mm} \mathrm{seg}^{-1}$ was measured.

\section{Acid and soluble solids contents}

Apple juice samples were obtained from 10 apples and titrated with $0.1 \mathrm{~N} \mathrm{NaOH}$ to a $\mathrm{pH} 8.2$ endpoint, then the acidity was expressed as \% of malic acid. Total soluble solids (TSS) in the juice were determined with a refractometer ATC-1E (Atago Ltd; Tokyo, Japan) in CHIH, and a Reichert ABBE Mark II refractometer (AO Scientific Instruments; Keene, NH, USA) in WA.

\section{Aroma volatiles}

Concentration of volatiles in apples was determined by gas chromatography-mass spectrometry using the solid phase micro extraction (SPME) technique. Apple juice from 10 apples was obtained with a food processor (Turmix; Mexico) in CHIH, and with a Champion Juicer (Lodi; CA, USA) in WA. A $20 \mathrm{~mL}$ juice sample was placed in a $20 \mathrm{~mL}$ plastic scintillation vial, frozen in liquid nitrogen, and kept at $-70^{\circ} \mathrm{C}$ until analysis. An aliquot of $2 \mathrm{~mL}$ of thawed apple juice was placed in a $4 \mathrm{~mL}$ vial containing $0.7 \mathrm{~g}$ of sodium chloride and stirred while a SPME fiber (65 $\mathrm{m}$, PDMS-DVB, Supelco USA) was exposed to the headspace of the sample for $1 \mathrm{~h}$ at room temperature $\left(25^{\circ} \mathrm{C}\right)$. The fiber was desorbed by splitless injection, using a SPME liner, for 5 min at $200^{\circ} \mathrm{C}$ into a GC-MS system (Varian Saturn 2100D GC/MS; Walnut Creek, CA, USA) equipped with an Equity-1 column $(60 \mathrm{~m} \times 0.25 \mathrm{~mm}$ ID $\times 0.25 \mu \mathrm{m}$ film thickness, Supelco USA). Chromatography conditions were as follows: initial oven temperature of $33^{\circ} \mathrm{C}$ held for $5 \mathrm{~min}$, increased to $50^{\circ} \mathrm{C}$ at $2{ }^{\circ} \mathrm{C} / \mathrm{min}$, increased to $250^{\circ} \mathrm{C}$ at $5^{\circ} \mathrm{C} \mathrm{min}^{-1}$, and held for $6.5 \mathrm{~min}$. Helium was used as the carrier gas with a linear velocity of $30 \mathrm{~cm} \mathrm{~s}^{-1}$. The GC/MS and column used in WA and CHIH to analyse volatiles from apple juice was similar to Olivas et al. (2007). Mass spectra were obtained by electron impact ionization at $70 \mathrm{eV}$. Transfer line and ion source temperatures were 250 and $180^{\circ} \mathrm{C}$, respectively. Spectra were recorded with a Saturn GC/MS workstation (Varian). Identification of the volatile organic compounds (VOCs) of interest was made by matching their spectra with those of the NIST 98 MS library and by comparing the retention times against those of high purity standards (Sigma-Aldrich and ChemService). Quantification was accomplished by external standard calibration curves integrating the peak areas. All values represent the average of 3 pooled samples from 10 apples. 
Statistical analysis

Two independent studies were conducted, one studying 'Red Delicious' apples, and one studying 'Golden Delicious' apples. On each one of the experiments, "geographical region" was studied as the relevant factor (WA vs. $\mathrm{CHIH}$ ). The effect of geographical region on slopes, means and specific values at the commercially accepted ripening point ( 1 ppm IEC) were compared. Three consecutive years were studied as replications. Statistical analysis was performed using SAS ${ }^{\mathrm{TM}}$ (Statistical analysis System, version 8.0). A oneway ANOVA was conducted.

\section{Results and Discussion}

The present study compares the differences in 'Golden Delicious' (GD) and 'Red Delicious' (RD) apples produced in Washington (WA) and in Chihuahua (CHIH), and evaluates how environmental conditions, such as temperature, daylight hours, and altitude, among others, may influence the quality characteristics of the fruit. According to Faust (2000), WA and CHIH have different climates that may influence the general physiology of the apple trees. While Washington State offers an arid climate with warm days and cool nights, Chihuahua State is characterized by a climate with warm days and nights with moderate temperatures. Both regions receive about $400 \mathrm{~mm}$ of rain per year. Results show that WA trees took 34-42 days longer than CHIH trees to bloom. This delay in the flowering of WA trees may be due to lower temperatures in that area. Table 2 shows higher temperatures before flowering in $\mathrm{CHIH}$ compared to WA. According to Guédon and Legave (2008), higher temperatures cause early flowering; this may be explained by the completion of heat requirements in trees.

\section{Internal Ethylene Concentration IEC}

Apples are climacteric fruits whose ripening is associated with an increase in ethylene production (Reid et al., 1973). The optimal harvest date coincides with the beginning of the climacteric rise, followed by the rise in ethylene beyond a threshold of $1 \mu \mathrm{L} \mathrm{L}^{-1}$ in 'Delicious' apples (Fellman et al., 2003). Overripe fruit has short storage life, while fruit harvested at an immature stage has low quality and can be more susceptible to physiological disorders (Bai et al., 2009). Therefore, picking apple fruit at an optimum maturity is essential. In the present study, quality comparisons between zones were performed at $1 \mu \mathrm{L} \mathrm{L}^{-1} \mathrm{IEC}$, which is considered an ethylene threshold, beyond what a marked rise in IEC is observed. According to Fellman et al. (2003), apples harvested at $1 \mu \mathrm{L} \mathrm{L}^{-1}$ IEC presented the highest overall rating by an untrained taste panel (considering one week of postharvest storage under $25^{\circ} \mathrm{C}$ ).

Figure 1 shows the ethylene production of GD and RD apples grown in WA and $\mathrm{CHIH}$. The onset in ethylene production $\left(\sim 1 \mu \mathrm{L} \mathrm{L}^{-1}\right)$ was first observed in WA apples (152 DAFB for GD and 144 DAFB for RD) followed by CHIH apples (169 DAFB for GD and 169 DAFB for RD). The longer time needed by CHIH apples to achieve the onset in ethylene production could be due to the difference in elevation of the studied locations (2062 vs. 763 masl, CHIH and WA, respectively). According to Dhanaraj et al. (1986), 'Royal Delicious' and 'Red Delicious' apples at 2062 masl required more time to reach the same maturity stage than apples at 1675 masl. Danesin et al. (2004) found that 'Golden Delicious' apples cultivated at 900 masl showed a delay of ethylene biosynthesis and MACO2 and MCTR1 expression when compared to apples cultivated at 500 masl. Also, Dal Cin et al. (2007) found that the optimal apple harvest time was delayed at higher elevations (950 vs. 533 masl).

In the present study, higher ethylene values were observed in WA apples in comparison with $\mathrm{CHIH}$ apples (Figure 1). WA RD apples showed ethylene values up to $67 \mu \mathrm{L} \mathrm{L}^{-1}$ at 173 DAFB while CHIH apples barely reached $15 \mu \mathrm{L} \mathrm{L}^{-1}$ at 190 DAFB. WA GD showed values up to $34 \mu \mathrm{L} \mathrm{L}^{-1}$ at 158 DAFB while CHIH apples only reached $25 \mu \mathrm{L} \mathrm{L}^{-1}$, at $190 \mathrm{DAFB}$. Dal Cin et al. (2007) found that the amount of ethylene produced at harvest was much higher at lower elevations ( 533 masl) when compared to higher elevation sites ( 950 masl). 
The intensity of the environmental light could affect the amount of ethylene produced by apples. Nilsson and Gustavsson (2007) studied the effect of the apple position inside the canopy. They discovered that the ethylene peak was considerably higher in the shaded apples positioned inside the canopy with lower light intensity. In the present work, less solar radiation was observed in WA (Table 3).

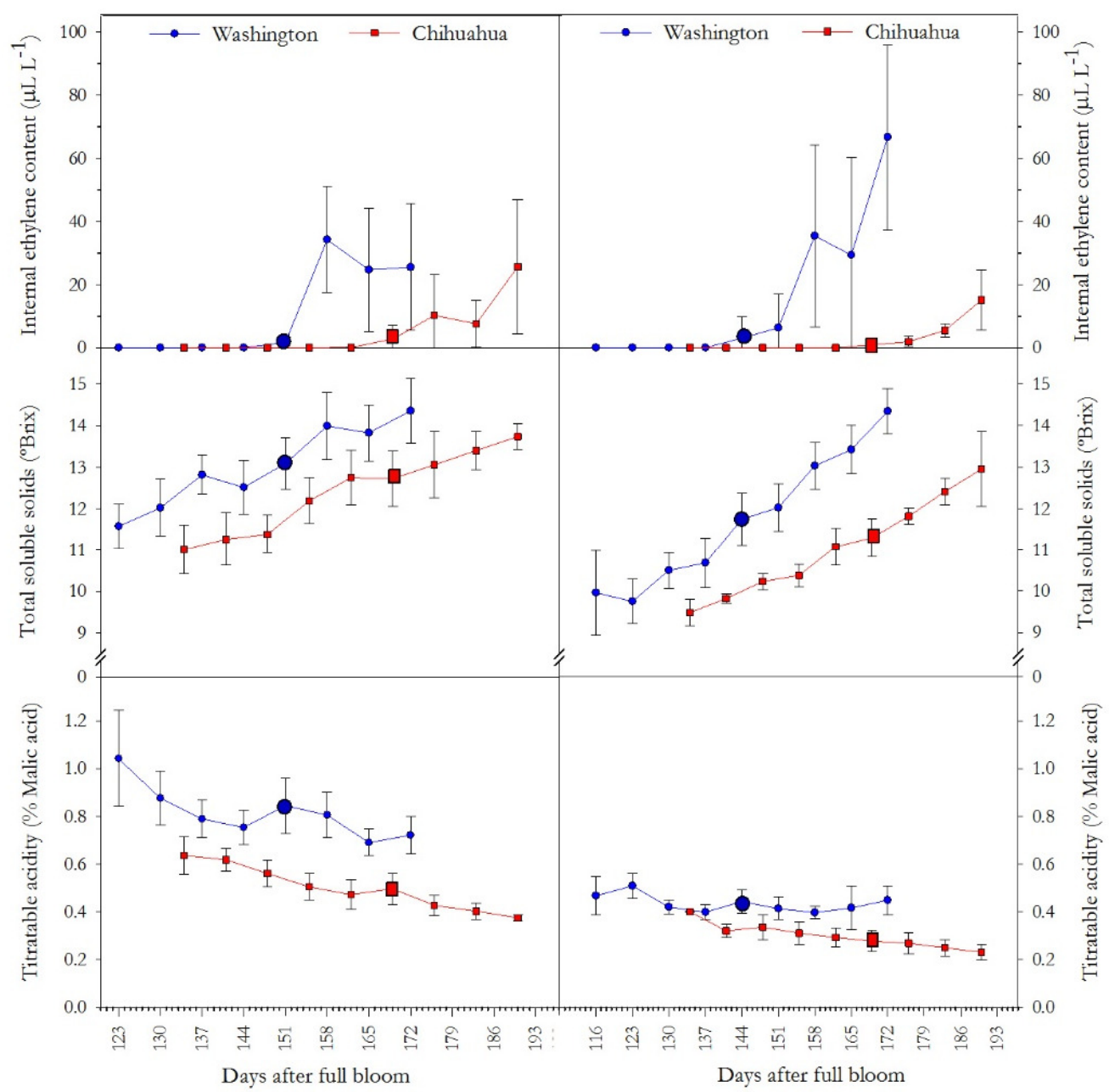

Figure 1. Internal ethylene concentration $\left(\mu \mathrm{L} \mathrm{L}^{-1}\right)$, total soluble solids ( $\left.{ }^{\circ} \mathrm{Brix}\right)$, and titratable acidity (\% Malic acid) during maturation of 'Golden Delicious' apples (left) and 'Red Delicious' apples (right) grown in Chihuahua, Mexico (CHIH) and Washington, USA (WA)

Vertical bars represent one standard deviation.

The ripening delay observed on $\mathrm{CHIH}$ apples (Figure 1) could be related to the photoperiod. Table 3 shows how apples from both zones needed the same photoperiod, $\sim 2,222 \mathrm{~h}$, to reach the beginning of the ripening stage ( $\left.1 \mu \mathrm{L} \mathrm{L}^{-1} \mathrm{IEC}\right)$. However, while WA attained this photoperiod at 144 and 151 DAFB for RD and GD apples, respectively, CHIH required longer time (169 DAFB for both varieties RD and GD) (Table 3). Figure 3 shows how $\mathrm{CHIH}$ presented less accumulated light hours, so longer time was required for $\mathrm{CHIH}$ apples to obtain the same photoperiod as WA. According to Dwyer and Stewart (1987), barley's phenological development rate is proportional to the photoperiod. According to Keating et al. (1998), temperate leguminous species mature earlier at more extended photoperiod. In this case WA apples have the longest photoperiod averaging of $14.74 \mathrm{~h} /$ day, compared with $13.44 \mathrm{~h} /$ day for $\mathrm{CHIH}$ apples. 


\section{Acidity and soluble solids contents}

Total organic acid content, measured as titratable acidity (TA), and the concentration of total soluble solids (TSS), expressed as ${ }^{\circ}$ Brix, are useful maturity indices measured in apples, in addition to the internal ethylene concentration, to determine optimum harvest date when long term storage is intended (Kingston, 1992; Bai et al., 2009). The acidity (sour taste) in the apple is given by organic acids such as malic, citric, and tartaric acids (Kader 2008; Wu et al., 2007). Malic acid, accumulated in the vacuoles (Khan et al., 2013), comprises about $90 \%$ of the acid content (Wu et al., 2007; Nour et al., 2010). Organic acids are used as substrates for the respiratory process, and the percentage of malic acid may decrease up to $40 \%$ in pome fruits during ripening (Ackermann et al., 1992; Knee, 1993). The TA varies with the cultivar, the season, and the orchard handling. Trad et al. (2013) found that in mountainous zones, fruits ripened earlier and were less acid.

The present work shows how titratable acidity is lower in $\mathrm{CHIH}$ apples when compared to WA apples. Malic acid at $\sim 1 \mu \mathrm{L} \mathrm{L}^{-1}$ IEC was $0.84 \%$ and $0.5 \%$ for GD apples and $0.4 \%$ and $0.3 \%$ for RD apples, for WA and $\mathrm{CHIH}$, respectively (Figure 1). Lower acidity on $\mathrm{CHIH}$ apples may be due to the higher solar radiation presented in CHIH compared to WA (Table 3). Nilsson and Gustavsson (2007) observed that apples outside of the tree, which received higher light intensity, presented lower titratable acidity when compared with fruit inside of the canopy. Altitude may also influence apple acidity. According to Timilsina and Tripathi (2019), titratable acidity lowers on mandarins as elevation increases. The present work shows how acidity was lower in the highest altitude area, CHIH (2062 masl) (Figure 1).

During apple senescence a decrease in starch is observed due to the activity of enzymes $\alpha$-amylase, $\beta$ amylase, and starch phosphorylase, which cause an increase in the sugar content (Azcon-Bieto and Talon, 1996). The sweetness of apple fruit is due to soluble solids, mainly fructose, glucose, and sucrose (Li et al., 2012). In the present study, the total soluble solids (TSS) increased over time in both varieties at both zones. No significant differences were found on TSS on WA and CHIH RD apples (11.7 and $11.3^{\circ} \mathrm{Bx}$, respectively) and GD apples (13.1 and $12.7^{\circ} \mathrm{Bx}$, respectively) at the onset of ethylene production $\left(1 \mu \mathrm{L} \mathrm{L}{ }^{-1} \mathrm{IEC}\right)$. Although there is no significant difference in TSS values at the same maturity stage, Figure 1 shows a lag in TSS development in CHIH. This probably happened because WA accumulates light hours faster than $\mathrm{CHIH}$ (Table 3). According to Choudhury et al. (2008), sucrose synthesis in bananas increases by increasing light exposure. Also, a high TSS content has been found on more sun-exposed apples (Drogoudi and Pantelidis, 2011) and peaches (Prunus persica L.) (Marini et al., 1991).

\section{Color and firmness}

Skin color and fruit firmness are two of the most important apple attributes to determine fruit maturity (Wills et al., 1981). Color changes are associated with changes in apples' metabolism during ripening, accompanied by changes in the chlorophyll content (Gross, 1987). The anthocyanins, which are water-soluble and accumulate in vacuoles, give the red colour to the apple skin (Lancaster and Dougall, 1992; Umemura, 2013); they are synthesized via the flavonoid pathway, a branch of the phenylpropanoid pathway (Takos et al., 2006). In apple skin, the formation of anthocyanin is sunlight-dependent, mainly UV-B (280-320 nm) (Arakawa et al., 1985; Arakawa, 1988; Saure, 1990; Steyn et al., 2009). This process is enhanced by light exposure, cool nights and warm sunny days before harvest (Kingston, 1992).

No significant differences were found in the color of WA and CHIH apples (GD and RD) (Figure 2, Table 4), in contradiction with previous studies that show that solar radiation favors red coloration (Jakopic et al., 2007; Drogoudi and Pantelidis, 2011; Baiamonte et al., 2016) and a more developed yellow color (Ordoñez et al., 2016). According to Jakopic et al. (2007 and 2010), greater light intensity induces anthocyanin synthesis. The present study did not show that higher solar radiation would induce red coloration in $\mathrm{RD}$ apples grown in CHIH (area with the highest solar radiation, Table 3). According to Dussi et al. (2005), if the solar radiation is not low enough, colour development may be achieved.

Firmness is an important indicator of apple quality (Huxsoll et al., 1989). A texture difference of at least $6 \mathrm{~N}$ can be perceived by a trained panel (Harker et al., 2002). Firmness could be affected by pre-harvest factors 
related to the crop area, such as temperature, daylight hours, and solar radiation, among others (Sams, 1999). During maturation, there was a decrease in firmness of apples from both studied regions with no differences in the reduction rate (Figure 2, Table 4), which, according to Johnston et al. (2002), is due to the disruption of the middle lamella, responsible of cell adhesion and cell packing.

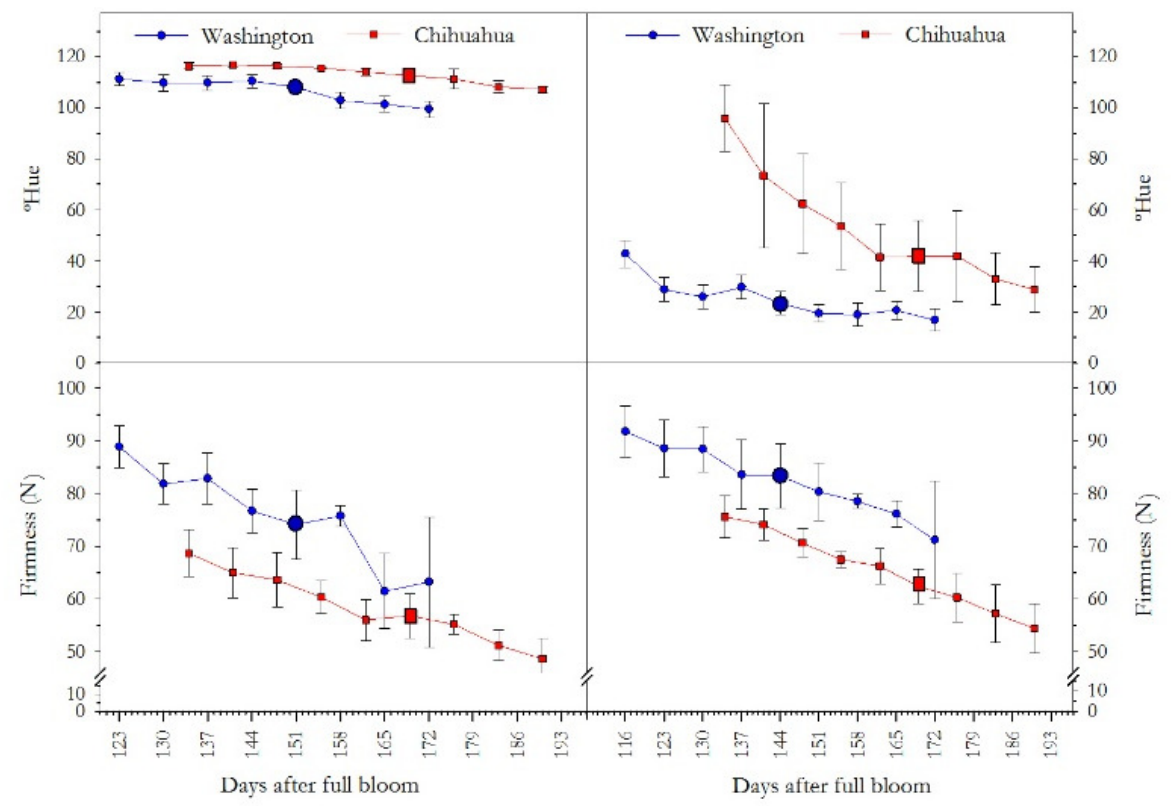

Figure 2. Hue angle ( $\left.{ }^{\circ} \mathrm{Hue}\right)$, and Firmness $(\mathrm{N})$ during maturation of 'Golden Delicious' apples (left) and 'Red Delicious' apples (right) grown in Chihuahua, Mexico (CHIH) and Washington, USA (WA) Vertical bars represent one standard deviation.

Table 4. Quality parameters for 'Golden Delicious' and 'Red Delicious' apples grown in Washington, USA (WA) and Chihuahua, México (CHIH)

\begin{tabular}{|c|c|c|c|c|c|c|c|c|c|c|c|c|c|}
\hline \multirow{2}{*}{ Cultivar } & \multirow{2}{*}{ Zone } & \multicolumn{3}{|c|}{ Firmness } & \multicolumn{3}{|c|}{ TSS } & \multicolumn{3}{|c|}{ Color } & \multicolumn{3}{|c|}{ Malic acid } \\
\hline & & Slope $^{1}$ & Mean $^{2}$ & $\mathrm{~N}^{3}$ & Slope $^{1}$ & Mean $^{2}$ & ${ }^{\circ} \mathrm{Bx}^{3}$ & Slope $^{1}$ & Mean $^{2}$ & $\mathrm{Hue}^{3}$ & Slope $^{1}$ & Mean ${ }^{2}$ & $\%^{3}$ \\
\hline \multirow{2}{*}{$\begin{array}{c}\text { 'Golden } \\
\text { Delicious' }\end{array}$} & WA & $-0.509^{\mathrm{a}}$ & $73.7^{a}$ & $74.15^{\mathrm{a}}$ & $0.0535^{\mathrm{a}}$ & $13.1^{1}$ & $13.09^{2}$ & $-0.2817^{\mathrm{a}}$ & $105.91^{\mathrm{b}}$ & $107.74^{2}$ & $-0.0031^{2}$ & $0.78^{\mathrm{a}}$ & $0.84^{\mathrm{a}}$ \\
\hline & CHIH & $-0.329^{2}$ & $60.8^{\mathrm{b}}$ & $56.84^{\mathrm{b}}$ & $0.0533^{a}$ & $12.7^{\mathrm{a}}$ & $12.73^{a}$ & $-0.1317^{\mathrm{b}}$ & $114.70^{a}$ & $112.63^{2}$ & $-0.0049^{\mathrm{a}}$ & $0.53^{b}$ & $0.50^{\mathrm{b}}$ \\
\hline \multirow{2}{*}{$\begin{array}{c}\text { 'Red } \\
\text { Delicious' }\end{array}$} & WA & $-0.337^{\mathrm{a}}$ & $83.01^{2}$ & $80.0^{2}$ & $0.0907^{2}$ & $11.7^{\mathrm{a}}$ & $11.74^{2}$ & $-0.2726^{a}$ & $22.80^{\mathrm{a}}$ & $23.48^{2}$ & $-0.0003^{2}$ & $0.41^{2}$ & $0.44^{a}$ \\
\hline & CHIH & $-0.388^{a}$ & $65.87^{\mathrm{b}}$ & $62.4^{b}$ & $0.0558^{b}$ & $11.3^{\mathrm{a}}$ & $11.30^{2}$ & $-1.0044^{1}$ & $55.73^{a}$ & $41.88^{2}$ & $-0.0022^{\mathrm{a}}$ & $0.31^{2}$ & $0.28^{a}$ \\
\hline
\end{tabular}

${ }^{1}$ Slopes corresponding to data ranging from 130 to 173 DAFB for WA and from 134 to 176 DAFB for CHIH.

${ }^{2}$ Means corresponding to data ranging from 130 to 173 DAFB for WA and from 134 to 176 DAFB for CHIH.

${ }^{3}$ Values obtained when internal ethylene concentration (IEC) in apples was $\sim 1 \mu \mathrm{L} \mathrm{L}^{-1}$. Golden Delicious: 169 and 151

DAFB for CHIH and WA, respectively. Red Delicious: 169 and 144 DAFB for CHIH and WA, respectively.

Different upper-case letters among zone for each cultivar indicate statistically significant differences $(\mathrm{p} \leq 0.05)$.

For both cultivars, RD and GD, WA apples showed considerably higher firmness values during the study when compared to CHIH apples (Figure 2, Table 4), for both cultivars. To better understand the possible effects of the environment in the two studied regions, photothermal units were calculated, and their correlation with firmness was analysed. Under a specific temperature, a given plant cannot develop; above a specific temperature, plants slow down their growth and eventually stop. A heat unit accumulates, when the average temperature of the day exceeds the lower critical point of development of the plant by one degree. It has been shown that photothermal units correlate better with plant development than heat units. So, photothermal units are obtained multiplying the light hours by the day degrees. Figure 3 shows how the photothermal units accumulated as the days after full bloom progressed. It can be seen that $\mathrm{CHIH}$ accumulated higher photothermal unit values when compared to WA. 

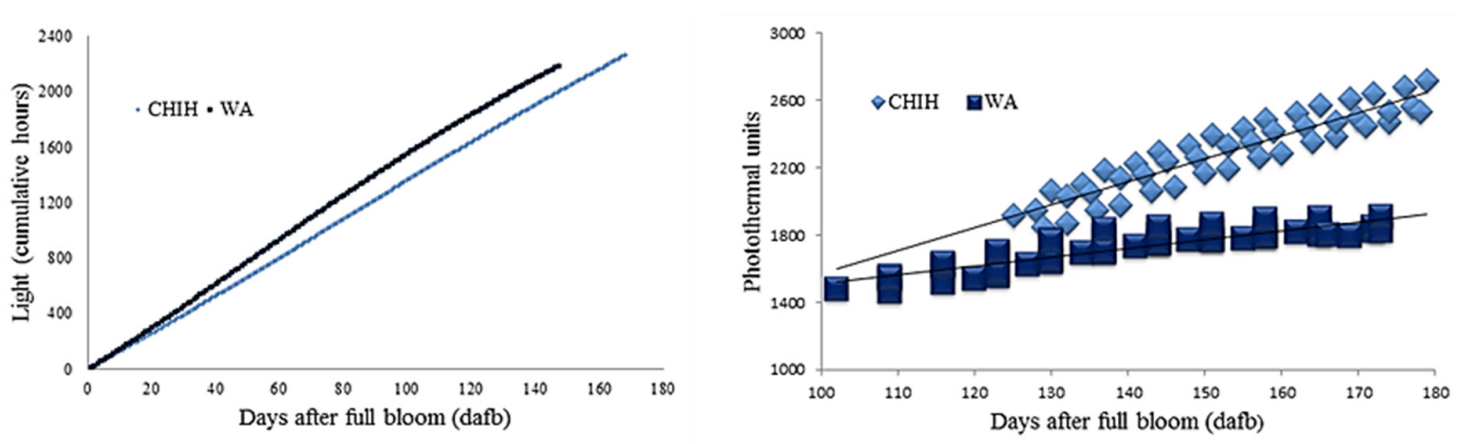

Figure 3. Photoperiod (cumulative light hours), and photothermal units (cumulative), from bloom to harvest. Data pooled from two varieties, and three seasons

According to Dwyer and Stewart (1987), barley's phenological development (Hordeum vulgare Bruce) varies as a function of heat units. A high correlation between the apples' firmness and the photothermal units was observed in this study (Figure 4), with a strong correlation coefficient $(r=0.89)$. Figure 4 shows three-year data on GD and RD apples grown in both areas, WA and CHIH. This figure shows that photothermal units correlate with apple firmness, meaning that day-light and temperature are the main factors affecting apple firmness. The present work shows that photothermal units could be an excellent predictor of firmness in apples and that when manipulating photothermal units (temperature and light hours), the apple firmness could be controlled. More studies are needed to confirm this hypothesis.

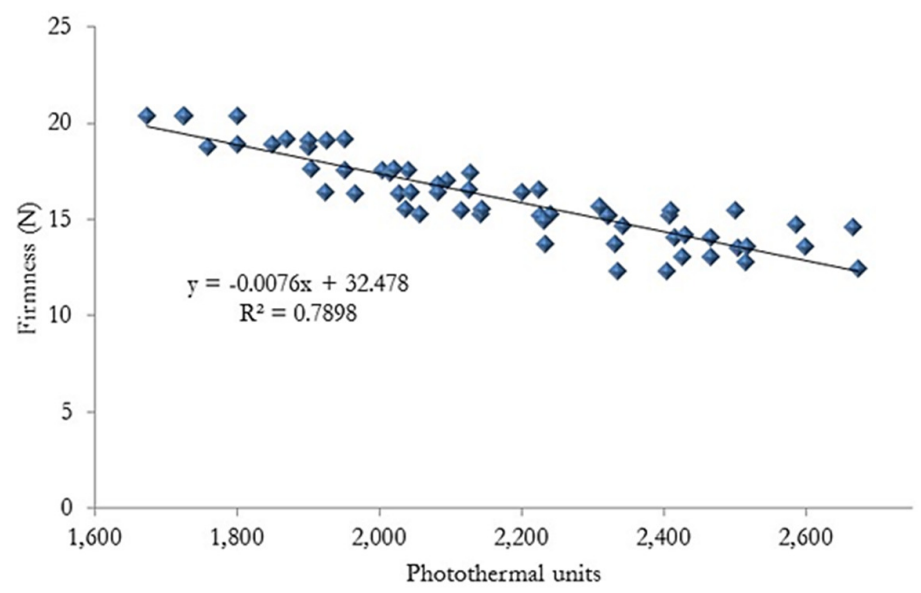

Figure 4. Apple firmness dependence on photothermal units

Firmness values include 'Golden Delicious' and 'Red Delicious' apples from Chihuahua, Mexico (CHIH) and Washington, USA (WA), on three consecutive years.

\section{Aroma volatiles}

More than 300 volatile compounds have been identified in apples, being the main volatiles aldehydes, alcohols, and esters. Aldehyde synthesis is considered the first step in the production of volatiles, followed by alcohols, being esters the last ones synthesized (Pérez et al., 2008; Espino-Díaz et al., 2016). Esters are the most important compounds that contribute to ripe apples' aroma, followed by alcohols (Dimick et al., 1983; Dunemann et al., 2012; Espino-Díaz et al., 2016). In the present study three alcohols (1-butanol, 2-methyl-1butanol, and 1-hexanol) and three esters (butyl acetate, 2-methyl butyl acetate, and hexyl acetate) were analysed, as they are considered among the most important in apples due to their high content and impact on apple 
aroma. The results of volatile aroma compounds are shown in Figures 5 and 6 . As apple maturity develops, an increase in volatile compounds is observed, following the ethylene pattern. An increase in volatile production was observed at the IEC onset for WA apples (Figures 5 and 6). The same behaviour was observed on esters for $\mathrm{CHIH}$ apples. According to Song and Bangerth (1996), an increase in autocatalytic ethylene production may be essential for increasing aroma volatile production. According to Fellman et al. (2003), major volatile production is closely linked to the onset of climacteric ripening.

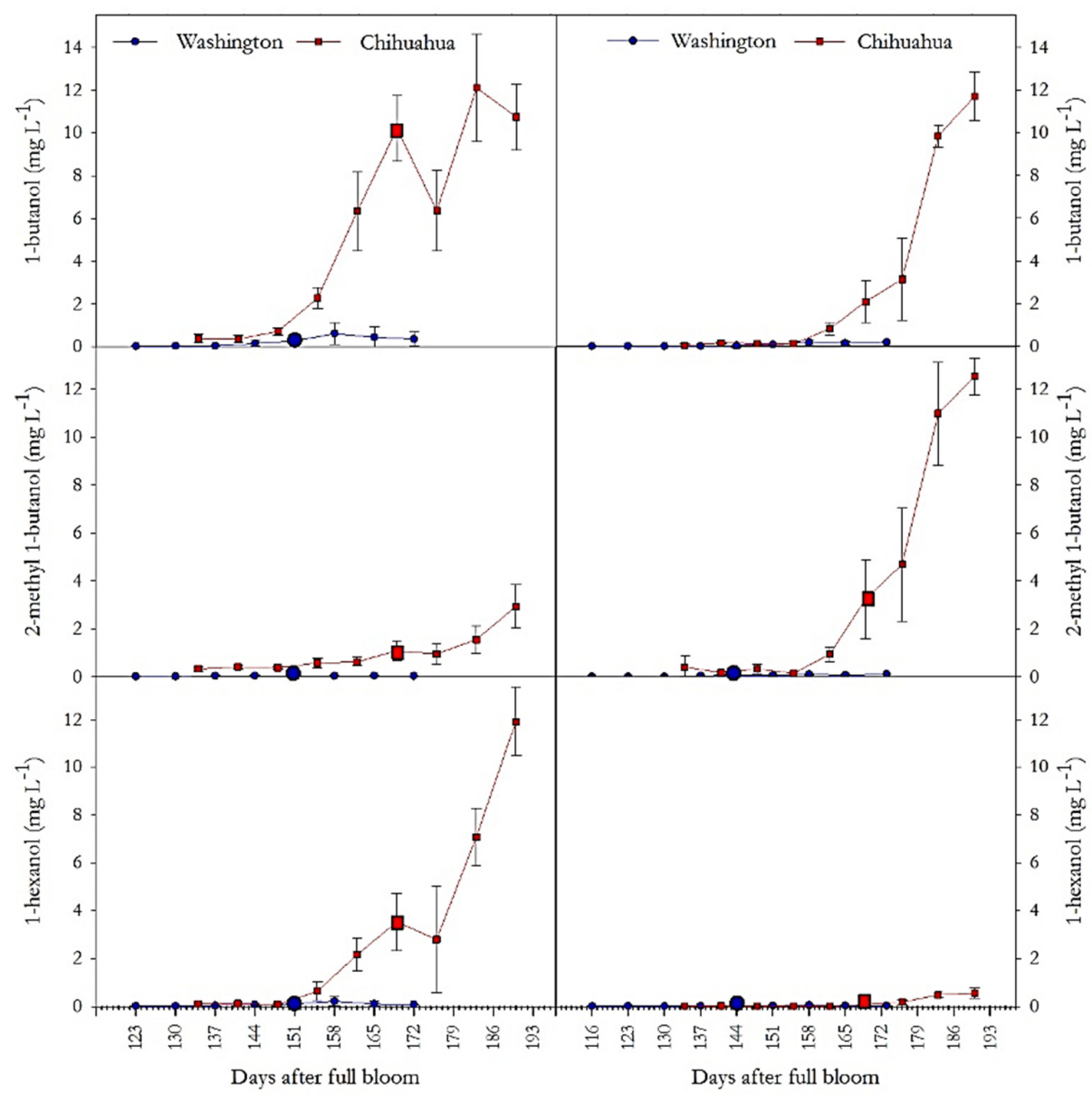

Figure 5. Production of alcohols 1-butanol, 2-methyl 1-butanol, and 1-hexanol, (mg L $\left.\mathrm{L}^{-1}\right)$ during maturation of 'Golden Delicious' apples (left) and 'Red Delicious' apples (right) grown in Chihuahua, Mexico (CHIH) and Washington, USA (WA)

Vertical bars represent one standard deviation.

Regardless of the production area, a higher concentration of 1-butanol and butyl acetate was found in GD apples (Figures 5 and 6). Similarly, other authors have found that the most abundant volatile aroma compounds in GD apples are 1-butanol and butyl acetate (Song and Bangerth, 1996; López et al., 1998; Kondo et al., 2005; Salas et al., 2011). A higher concentration of 2-methyl-1-butanol and 2-methyl butyl acetate was found in RD apples (Figure 5). According to Rowan et al. (1999), high production of 2-methyl butyl acetate seems to be characteristic of the RD apples. These results suggest different enzymatic activities between cultivars contribute to the variation in volatile esters' accumulation, as reported by Rowan et al. (1999) and Holland et al. (2005).

At the onset in ethylene production ( $\left.1 \mu \mathrm{L} \mathrm{L}^{-1} \mathrm{IEC}\right)$, higher concentrations of 1-butanol, butyl acetate, 1-hexanol, butyl acetate, 2-methyl-1-butanol were observed in CHIH apples $(\mathrm{p} \leq 0.05)$ when compared to WA 
apples (Figures 5 and 6). No statistical difference was observed in 2-methyl butyl acetate of CHIH and WA apples ( $\mathrm{p} \leq 0.05$ ). The concentration of 1-butanol and butyl acetate compounds in $\mathrm{CHIH}$ apples was 30 and 10 -fold higher than in WA apples when the IEC reached $1 \mu \mathrm{L} \mathrm{L}^{-1}$. In the case of 1-hexanol, GD apples from $\mathrm{CHIH}$ showed a 12-fold concentration increment in comparison with WA apples, while in $\mathrm{RD}$ apples from both areas, the content of this alcohol remained very low. These results show that $\mathrm{CHIH}$ apples have a greater capacity to produce volatile aroma compounds than WA apples. The variety, the characteristics of the zone (light intensity, precipitation, temperature differences, soil conditions), and the effect of altitude (variation in temperature, humidity, and solar radiation), seem to affect the regulation of the volatile compound biosynthesis (Dhanaraj et al., 1986; Jiang et al., 2013; Jin et al., 2017).

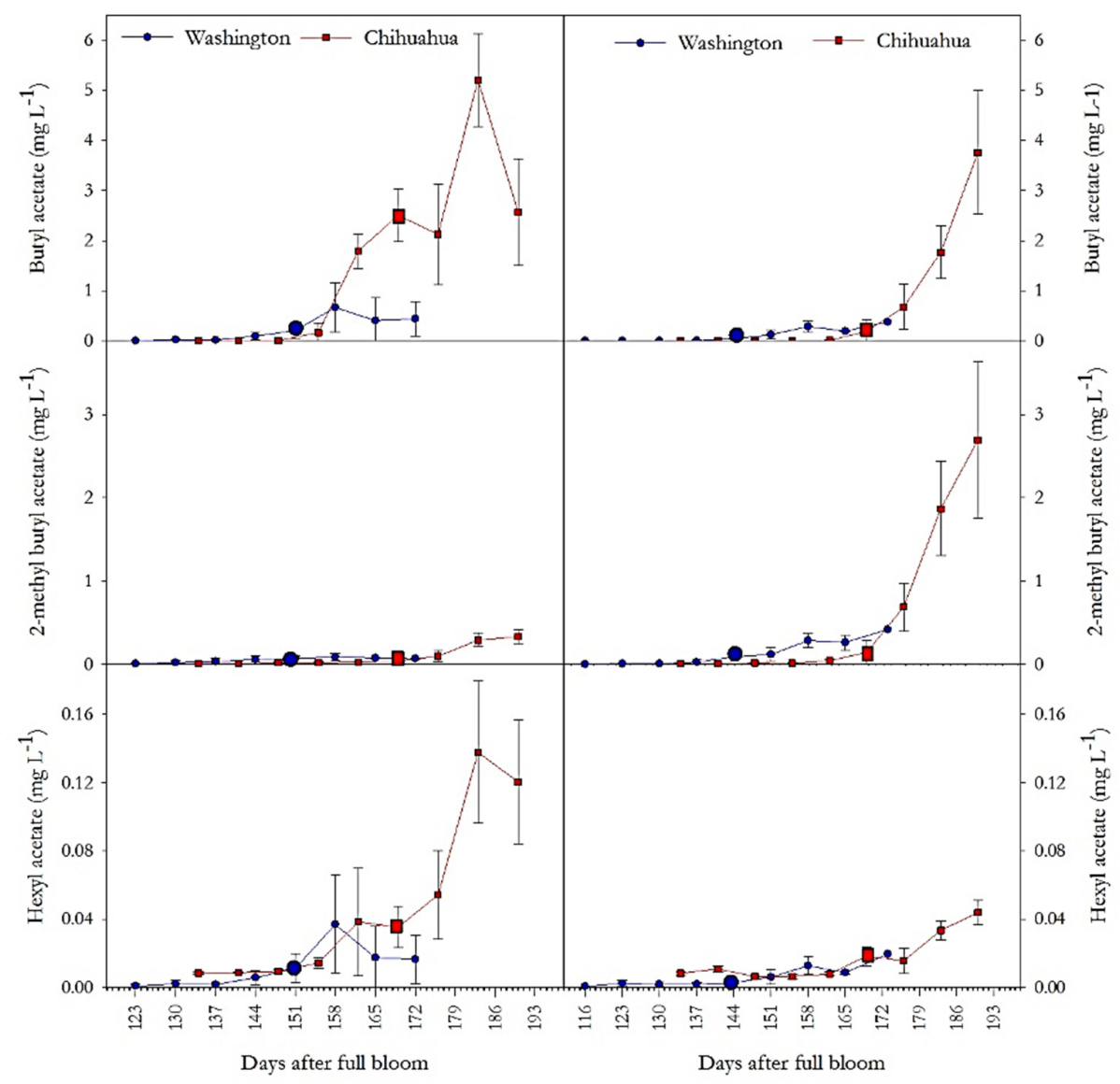

Figure 6. Production of esters hexyl acetate, 2-methyl butyl acetate, and butyl acetate $\left(\mathrm{mg} \mathrm{L}^{-1}\right)$ during maturation of 'Golden Delicious' apples (left) and 'Red Delicious' apples (right) grown in Chihuahua, Mexico (CHIH) and Washington, USA (WA)

Vertical bars represent one standard deviation.

After the onset in ethylene production, volatiles increased markedly, with a considerably higher volatile production rate and volatile concentration on $\mathrm{CHIH}$ apples (Figures 5 and 6). Variations in the composition and content of volatile compounds have been attributed to the climate, elevation, or geographic location, for its effect on the activity of some enzymes (Qin et al., 2017). The higher concentration in volatile compounds found in CHIH apples may be due to the considerably higher altitude in CHIH compared to WA (2062 vs. 763 masl). Some studies report that altitude has a marked influence on grape aroma production; low-altitude sites induce lower amounts of aroma compounds in grapes and wines (Jiang et al., 2013; Xu et al., 2015; 
Alessandrini et al., 2019). In bananas, the 'Robusta' cultivar showed a higher content of ketones and esters at high altitudes (Brat et al., 2004). Production of aroma in tea leaf (Camellia sinensis L.) was higher in high altitudes (Bhattacharya and Sen-Mandis, 2011). Pomegranate (Punica granatum L.) fruit showed higher concentrations of volatile compounds at higher altitudes (Mphahlele et al., 2016).

Additionally, the higher production of volatile compounds in $\mathrm{CHIH}$ apples may also be caused by the stronger solar radiation in this area (Table 3). According to Song et al. (2015), the incidence of light increases the concentration of volatile compounds in grapes. Volatile compound formation increases together with increasing light exposure of the fruit (Miller et al., 1998). According to Ordoñez et al. (2016), lower photosynthetically available radiation caused by black hail nets in comparison with white hail nets, causes a decrease in the concentration of the main aroma compounds in GD apples. Baiamonte et al. (2016) also reported that the use of hail net reduced the concentration of compounds such as butyl acetate and hexenyl acetate.

\section{Conclusions}

Apples from two different regions, WA and $\mathrm{CHIH}$, showed variations in the development of quality characteristics during their maturation in the tree. Environmental variables and their meteorological indices could account for these quality differences. Lower temperatures before bloom may be the reason for WA to bloom later than $\mathrm{CHIH}$. Apples from $\mathrm{CHIH}$ took longer to achieve the onset in ethylene production, which could be explained by the higher elevation when compared to WA. Apples from both zones reached the beginning of ripening after achieving the same photoperiod. The main quality differences between WA and $\mathrm{CHIH}$ apples were aroma volatiles, and texture. $\mathrm{CHIH}$ apples showed a higher aroma concentration which may be related to their higher altitude and solar radiation incidence. WA apples showed higher firmness compared to CHIH, possibly due to a lower accumulation of photothermal units in Washington. Our results show a strong correlation coefficient $(\mathrm{R}=0.89)$ between changes in apples' firmness and the accumulated photothermal units. To the extent of our knowledge this observation is reported here for the first time. More studies dealing with this correlation are necessary to better understand the nature of this relationship.

\section{Authors' Contributions}

JM-C: data acquisition, data analysis, formal analysis, writing and editing; M E-D: data analysis, data curation, writing and editing; JLJ-C: formal analysis, investigation; SM: design of methodology, data acquisition, data curation; JKF: conceptualization, supervision, design of methodology; DS: investigation, writing, and editing; GG-A: Design of methodology, investigation; NS-S: data acquisition, methodology, data analysis; GIO: conceptualization, visualization, supervision, design of methodology, writing and editing.

All authors read and approved the final manuscript.

\section{Acknowledgements}

This work was supported by the Mexican National Council of Science and Technology (CONACYT) and Chihuahua State Government through the grants CHIH-C01-21894 and CHIH-C01-92083 FOMIX. Authors thank Grupo la Norteñita, and Unión Agricola Regional de Fruticultores del Estado de Chihuahua UNIFRUT for their support. 
Molina-Corral FJ et al. (2021). Not Bot Horti Agrobo 49(1):12241

\section{Conflict of Interests}

The authors declare that there are no conflicts of interest related to this article.

\section{References}

Ackermann J, Fischer M, Amado R (1992). Changes in sugars, acids, and amino acids during ripening and storage of apples (cv. Glockenapfel). Journal of Agricultural and Food Chemistry 40(7):1131-1134. https://doi.org/10.1021/jf00019a008

Alessandrini M, Gaiotti F, Belfiore N, Matarese F, D'Onofrio C, Tomasi D (2019). Influence of vineyard altitude on Glera grape ripening (Vitis vinifera L.): effects on aroma evolution and wine sensory profile. Journal of the Science of Food and Agriculture 97(9):2695-2705. https://doi.org/10.1002/jsfa.8093

Arakawa O, Hori Y, Ogata R (1985). Relative effectiveness and interaction of ultraviolet-B, red and blue light in anthocyanin synthesis of apple fruit. Physiologia Plantarum 64(3):323-327. https://doi.org/10.1111/j.13993054.1985.tb03347.x

Arakawa O (1988). Photoregulation of anthocyanin synthesis in apple fruit under UV-B and red light. Plant Cell Physiology 29(8):1385-1389. https://doi.org/10.1093/oxfordjournals.pcp.a077651

Azcon-Bieto J, Talon M (1996). Fisiología y Bioquímica vegetal. McGraw-Hill-Interamericana, México.

Bai J, Prange RK, Toivonen PMA (2009). Pome fuits. In: Yahia EM (Ed). CRC Press, Taylor \& Francis Group LLC. Boca Raton, FL. pp 267-285.

Baiamonte I, Raffo A, Nardo N, Moneta E, Peparaio M, D'Aloise A, ... Casera C (2016). Effect of the use of anti-hail nets on codling moth (Cydia pomonella) and organoleptic quality of apple (cv. Braeburn) grown in Alto Adige Region (northern Italy). Journal of the Science of Food and Agriculture 96(6)2025-2032. https://doi.org/10.1002/jsfa.7313

Bhattacharya S, Sen-Mandis S (2011). Variation in antioxidant and aroma compounds at different altitude: A study on tea (Camellia sinensis L. Kuntze) clones of Darjeeling and Assam, India. African Journal of Biochemistry Research 5(5)148-159. https://doi.org/10.5897/AJBR.9000260

Brat P, Yahia A, Chillet M, Bugaud C (2004). Influence of cultivar, growth altitude and maturity stage on banana volatile compound composition. Fruits 59(2):75-82. https://doi.org/10.1051/fruits:2004007

Choudhury SR, Roy S, Das R, Sengupta DN (2008). Differential transcriptional regulation of banana sucrose phosphate synthase gene in response to ethylene, auxin, wounding, low temperature and different photoperiods during fruit ripening and functional analysis of banana SPS gene promoter. Planta 229(1):207-223. https://doi.org/10.1007/s00425-008-0821-2

Dal Cin VD, Danesin M, Botton A, Boschetti A, Dorigoni A, Ramina A (2007). Fruit load and elevation affect ethylene biosynthesis and action in apple fruit (Malus domestica L. Borkh) during development, maturation and ripening. Plant Cell \& Environment 30(11):1480-1485. https://doiorg/10.1111/j.1365-3040.2007.01723.x

Danesin M, Dal Cin V, Ramina A, Comai M, Dorigoni A, Boschetti A (2004). Effect of altitude and fruit load on molecular aspects of apple maturation (Malus pumila Mill.; Trentino). Rivista di Frutticoltura e di Ortofloricoltura 66:54-57.

Dhanaraj S, Krishnaprakash MS, Arvindaprasad B, Ananthakrishna SM, Krishnaprasad CA, Narasimham P (1986). Effect of orchard elevation on maturity and quality of apples 1. Journal of Food Quality 9(3):129-142. https://doi.org/10.1111/j.1745-4557.1986.tb00783.x

Dimick PS, Hoskin JC, Acree TE (1983). Review of apple flavor-state of the art. Critical Reviews in Food Science \& Nutrition 18(4):387-409. https://doi.org/10.1080/10408398309527367

Drogoudi PD, Pantelidis G (2011). Effects of position on canopy and harvest time on fruit physico-chemical and antioxidant properties in different apple cultivars. Scientia Horticulturae 129(4):752-760. https://doi.org/10.1016/j.scienta.2011.05.036

Dunemann F, Ulrich D, Malysheva-Otto L, Weber WE, Longhi S, Velasco R, Costa F (2012). Functional allelic diversity of the apple alcohol acyl-transferase gene MdAAT1 associated with fruit ester volatile contents in apple cultivars. Molecular Breeding 29(3):609-625. https://doi.org/10.1007/s11032-011-9577-7 
Dussi MC, Giardina G, Sosa D, Reeb P (2005). Shade nets effect on canopy light distribution and quality of fruit and spur leaf on apple cv. Fuji. Spanish Journal of Agricultural Research 2:253-260. http://dx.doi.org/10.5424/sjar/2005032-144

Dwyer LM, Stewart DW (1987). Influence of photoperiod and water stress on growth, yield and development rate of barley measured in heat units. Canadian Journal of Plant Science 67(1):21-34. https://doi.org/10.4141/cjps87003

Espino-Díaz M, González-Aguilar GA, Sepúlveda DR, Olivas GI (2016). Biochemistry of apple aroma: A review. Food Technology and Biotechnology 54(4):375-394. http://dx.doi.org/10.17113/ftb.54.04.16.4518

Faust M (2000). Physiological considerations for growing temperate-zone fruit crops in warm climates. In: Erez A (Ed). Temperate Fruit Crops in Warm Climates. Springer, Dordrecht pp 137-156. https://doi.org/10.1007/978-94017-3215-4_7

Fellman JK, Rudell DR, Mattinson DS, Mattheis JP (2003). Relationship of harvest maturity to flavor regeneration after CA storage of 'Delicious' apples. Postharvest Biology and Technology 27(1):39-51. https://doi.org/10.1016/S0925-5214(02)00193-X

Faniadis D, Drogoudi PD, Vasilakakis M (2010). Effects of cultivar, orchard elevation, and storage on fruit quality characters of sweet cherry (Prunus avium L.). Scientia Horticulturae 125(3):301-304. https://doi.org/10.1016/j.scienta.2010.04.013

Gross J (1987). Pigments in fruits (Food Science and Technology). Academic Press, Oxford.

Guédon Y, Legave JM (2008). Analyzing the time-course variation of apple and pear tree dates of flowering stages in the $\begin{array}{llll}\text { global warming } & \text { context. } & \text { Ecological } & \text { Modelling }\end{array}$ https://doi.org/10.1016/j.ecolmodel.2008.08.010

Harker FR, Maindonald J, Murray SH, Gunson FA, Hallett IC, Walker SB (2002). Sensory interpretation of instrumental measurements 1: texture of apple fruit. Postharvest Biology and Technology 24(3):225-239. https://doi.org/10.1016/S0925-5214(01)00158-2

Holland D, Larkov O, Bar-Ya'akov I, Bar E, Zax A, Brandeis E, ... Lewinsohn E (2005). Developmental and varietal differences in volatile ester formation and acetyl-CoA: alcohol acetyl transferase activities in apple (Malus domestica Borkh.) fruit. Journal of Agricultural and Food Chemistry 53(18):7198-7203. https://doi.org/10.1021/jf050519k

Huxsoll C, Bolin HR, King AD (1989). Physicochemical changes and treatments for lightly processed fruits and vegetables. In: Jen JJ (Ed). Quality Factors of Fruits and Vegetables. Chemistry and Technology. ACS Simposium Series, Washington, D.C. pp 201-215.

Jakopic J, Veberic R, Stampar F (2007). The effect of reflective foil and hail nets on the lighting, color and anthocyanins of 'Fuji' apple. Scientia Horticulturae 115(1):40-46. https://doi.org/10.1016/j.scienta.2007.07.014

Jakopic J, Stampar F, Veberic R (2010). Influence of hail net and reflective foil on cyanidin glycosides and quercetin glycosides in 'Fuji' apple skin. HortScience 45(10):1447-1452. https://doi.org/10.21273/HORTSCI.45.10.1447

Jiang B, Xi Z, Luo M, Zhang Z (2013). Comparison on aroma compounds in Cabernet Sauvignon and Merlot wines from four wine grape-growing regions in China. Food Research International 51(2):482-489. https://doi.org/10.1016/j.foodres.2013.01.001

Jin X, Wu X, Liu X (2017). Phenolic characteristics and antioxidant activity of Merlot and Cabernet Sauvignon wines increase with vineyard altitude in a high-altitude region. South African Journal of Enology and Viticulture 38(2):132-143. https://doi.org/10.21548/38-2-1068

Johnston JW, Hewett EW, Hertog ML (2002). Postharvest softening of apple (Malus domestica) fruit: a review. New Zealand Journal of Crop and Horticultural Science 30(3):145-160. https://doi.org/10.1080/01140671.2002.9514210

Kader AA (2008). Flavor quality of fruits and vegetables. Journal of the Science of Food and Agriculture 88(11):18631868. https://doi.org/10.1002/jsfa.3293

Kanchan J, Bhatia VS (2014). Impact of elevated temperatures on growth and yield of chickpea (Cicer arietinum L.). Field Crops Research 164:90-97. https://doi.org/10.1016/j.fcr.2014.06.003

Keatinge JDH, Aiming Q, Wheeler TR, Ellis RH, Summerfield RJ (1998). Effects of temperature and photoperiod on phenology as a guide to the selection of annual legume cover and green manure crops for hillside farming systems. Field Crops Research 57(2):139-152. https://doi.org/10.1016/S0378-4290(97)00122-6 
Khan SA, Beekwilder J, Schaart JG, Mumm R, Soriano JM, Jacobsen E, Schouten HJ (2013). Differences in acidity of apples are probably mainly caused by a malic acid transporter gene on LG16. Tree Genetics and Genomes 9(2):475-487. https://doi.org/10.1007/s11295-012-0571-y

Kingston CM (1992). Maturity indices for apple and pear. In: Janick J (Ed). Horticultural Reviews. Volume 13. American Society for Horticultural Science. John Wiley \& Sons, Inc. Toronto, Canada pp 407-432.

Knee M (1993). Pome Fruit: Biochemistry. In: Seymour GB, Taylor JE, Tucker GA (Eds). Biochemistry of Fruit Ripening. Chapman \& Hall, University Press, Cambridge, UK pp 329-336.

Kondo S, Setha S, Rudell DR, Buchanan DA, Mattheis JP (2005). Aroma volatile biosynthesis in apples affected by 1MCP and methyl jasmonate. Postharvest Biology and Technology 36(1):61-68. https://doi.org/10.1016/j.postharvbio.2004.11.005

Kronenberg HG (1983). Relationships between temperatures and blooming dates of apple trees. NJAS Wageningen Journal of Life Sciences 31(3):259-267. https://doi.org/10.18174/njas.v31i3.16949

Lancaster JE, Dougall DK (1992). Regulation of skin color in apples. Critical Reviews in Plant Sciences 10(6):487-502. https://doi.org/10.1080/07352689209382324

Li M, Feng F, Cheng L (2012). Expression patterns of genes involved in sugar metabolism and accumulation during apple fruit development. PLoS One 7(3):e33055. https://doi.org/10.1371/journal.pone.0033055

López ML, Lavilla MT, Riba M, Vendrell M (1998). Comparison of volatile compounds in two seasons in apples: Golden Delicious and Granny Smith. Journal of Food Quality 21(2):155-166. http://dx.doi.org/10.1111/j.17454557.1998.tb00512.x

McMaster GS, Wilhelm W (1997). Growing degree-days: one equation, two interpretations. Agricultural and Forest Meteorology 87(4):291-300. https://digitalcommons.unl.edu/usdaarsfacpub/83

Marini RP, Sowers D, Marini MC (1991). Peach fruit quality is affected by shade during final swell of fruit growth. Journal of the American Society for Horticultural Science 116(3):383-389. https://doi.org/10.21273/JASHS.116.3.383

Miller TW, Fellman JK, Mattheis JP, Mattinson DS (1998). Factors that influence volatile ester biosynthesis in 'Delicious' apples. Acta Horticulturae 464:195-200. https://doi.org/10.17660/ActaHortic.1998.464.27

Mphahlele RR, Caleb OJ, Fawole OA, Opara UL (2016). Effects of different maturity stages and growing locations on changes in chemical, biochemical and aroma volatile composition of 'Wonderful' pomegranate juice. Journal of the Science Food and Agriculture 96(3):1002-1009. https://doi.org/10.1002/jsfa.7186

Nilsson T, Gustavsson KE (2007). Postharvest physiology of 'Aroma' apples in relation to position on the tree. Postharvest Biology and Technology 43(1):36-46. https://doi.org/10.1016/j.postharvbio.2006.07.011

Nour V, Trandafir I, Ionica ME (2010). Compositional characteristics of fruits of several apple (Malus domestica Borkh.) cultivars. Notulae Botanicae Horti Agrobotanici Cluj-Napoca 38(3):228-233. https://doi.org/10.15835/nbha3834762

Olivas GI, Mattinson DS, Barbosa-Canovas GV (2007). Alginate coatings for preservation of minimally processed 'Gala' apples. Postharvest Biology and Technology 45(1):89-96. https://doi.org/10.1016/j.postharvbio.2006.11.018

Ordoñez V, Molina-Corral FJ, Olivas-Dorantes CL, Jacobo-Cuéllar JL, González-Aguilar G, Espino M, Sepúlveda D, Olivas GI (2016). Comparative study of the effects of black or white hail nets on the fruit quality of 'Golden Delicious' apples. Fruits 71(4):229-238. https://doi.org/10.1051/fruits/2016015

Pérez AG, Sanz C (2008). Formation of fruit flavour. In: Brückner B, Wyllie SG (Eds). Fruit and vegetable flavour. CRC Press Boston New York Washington, D. C. and Woodhead Publishing Limited, Cambridge England pp 41-70.

Qin L, Wei QP, Kang WH, Zhang Q, Sun J, Liu SZ (2017). Comparison of volatile compounds in 'Fuji' apples in the different regions in China. Food Science and Technology Research 23(1):79-89. https://doi.org/10.3136/fstr.23.79

Reid MS, Rhodes MJC, Hulme AC (1973). Changes in ethylene and $\mathrm{CO}_{2}$ during the ripening of apples. Journal of the Science and Food Agriculture 24(8):971-979. https://doi.org/10.1002/jsfa.2740240815

Rowan DD, Allen JM, Fielder S, Hunt MB (1999). Biosynthesis of straight-chain ester volatiles in Red Delicious and granny smith apples using deuterium-labeled precursors. Journal of Agricultural and Food Chemistry 47(7):25532562. https://doi.org/10.1021/jf9809028

Salas NA, Molina-Corral FJ, González-Aguilar GA, Otero A, Sepulveda DR, Olivas GI (2011). Volatile production by 'Golden Delicious' apples is affected by preharvest application of aminoethoxyvinylglycine. Scientia Horticulturae 130(2):436-444. https://doi.org/10.1016/j.scienta.2011.07.017

Sams CE (1999). Preharvest factors affecting postharvest texture. Postharvest Biology and Technology 15(3):249-254. https://doi.org/10.1016/S0925-5214(98)00098-2 
Saure MC (1990). External control of anthocyanin formation in apple. Scientia Horticulturae 42(3):181-218. https://doi.org/10.1016/0304-4238(90)90082-P

SIAP (2020). Servicio de Información Agroalimentaria y Pesquera. Anuario estadístico de la producción agrícola. Gobierno de México. Retrieved on March 042020 from https://nube.siap.gob.mx/cierreagricola/

Song J, Bangerth F (1996). The effect of harvest date on aroma compound production from 'Golden Delicious' apple fruit and relationship to respiration and ethylene production. Postharvest Biology and Technology 8(4):259-269. https://doi.org/10.1016/0925-5214(96)00020-8

Song J, Smart R, Wang H, Dambergs B, Sparrow A, Qian MC (2015). Effect of grape bunch sunlight exposure and UV radiation on phenolics and volatile composition of Vitis vinifera L. cv. Pinot Noir wine. Food Chemistry 173:424431. https://doi.org/10.1016/j.foodchem.2014.09.150

Steyn WJ, Wand SJ, Jacobs G, Rosecrance RC, Roberts SC (2009). Evidence for a photoprotective function of lowtemperature-induced anthocyanin accumulation in apple and pear peel. Physiologia Plantarum 136(4):461-472. https://doi.org/10.1111/j.1399-3054.2009.01246.x

Takos AM, Jaffe FW, Jacob SR, Bogs J, Robinson SP, Walker AR (2006). Light-induced expression of a MYB gene regulates anthocyanin biosynthesis in red apples. Plant Physiology 142(3):1216-1232. https://doi.org/10.1104/pp.106.088104

Timilsina K, Tripathi KM (2019). Chemical quality attributes of mandarin (Citrus reticulata Blanco) as affected by altitude and fruit bearing position in Kavre, Nepal. Archives of Agriculture and Environmental Science 4(3):319325. https://doi.org/10.26832/24566632.2019.0403010

Topping AJ (1981). A recording laboratory penetrometer for fruit. Journal of Agricultural Engineering Research 26(2):179-183. https://doi.org/10.1016/0021-8634(81)90069-X

Trad M, Gaaliche B, Renard CMGC, Marse M (2013). Inter- and intra-tree variability in quality of figs. Influence of altitude, leaf area and fruit position in the canopy. Scientia Horticulturae 162:49-54. https://doi.org/10.1016/j.scienta.2013.07.032

Umemura H, Otagaki S, Wada M, Kondo S (2013). Expression and functional analysis of a novel MYB gene, MdMYB110a_JP, responsible for red flesh, not skin color in apple fruit. Planta 238(1):65-76. https://doi.org/10.1007/s00425-013-1875-3

USDA (2020). United States Department of Agriculture. National Agricultural of Agriculture. Agricultural Statistics 2020. Chapter V, Statistics of fruits, tree nuts, and horticultural specialties. United States Government. Washington, D.C.

Wills RHH, Lee TH, Graham D, McGlasson WB, Hall EG (1981). Postharvest. An introduction to the Physiology and Handling of fruit and vegetables. A VI publishing, Westport, Conn. Granada, London. UK.

Wilsie CP (1962). Crop adaptation and distribution. Freeman W. H. and Co., London.

Wu J, Gao H, Zhao L, Liao X, Chen F, Wang Z, Hu X (2007). Chemical compositional characterization of some apple cultivars. Food Chemistry 103(1):88-93. https://doi.org/10.1016/j.foodchem.2006.07.030

Xu XQ, Liu B, Zhu BQ, Lan YB, Gao Y, Wang D, ... Duan CQ (2015). Differences in volatile profiles of Cabernet Sauvignon grapes grown in two distinct regions of China and their responses to weather conditions. Plant Physiology and Biochemistry 89:123-133. https://doi.org/10.1016/j.plaphy.2015.02.020
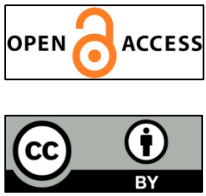

The journal offers free, immediate, and unrestricted access to peer-reviewed research and scholarly work. Users are allowed to read, download, copy, distribute, print, search, or link to the full texts of the articles, or use them for any other lawful purpose, without asking prior permission from the publisher or the author.

License - Articles published in Notulae Botanicae Horti Agrobotanici Cluj-Napoca are Open-Access, distributed under the terms and conditions of the Creative Commons Attribution (CC BY 4.0) License. (c) Articles by the authors; UASVM, Cluj-Napoca, Romania. The journal allows the author(s) to hold the copyright/to retain publishing rights without restriction. 